\title{
Influence of environmental factors on benthic macroinvertebrate communities of urban streams in Vereda habitats, Central Brazil
}

\author{
Influência de variáveis ambientais na comunidade de macroinvertebrados \\ bentônicos de córregos urbanos de Veredas, Brasil Central
}

\section{Renata de Moura Guimaraes Soutoํㅡ, Kátia Gomes Facure², Luis Alfredo Pavanin ${ }^{3}$ and Giuliano Buzá Jacobucci ${ }^{4}$}

\author{
'Programa de Pós-Graduaçáo em Ecologia e Conservaçáo de Recursos Naturais, \\ Universidade Federal de Uberlândia - UFU, CEP 38408-100, Uberlândia, MG, Brazil \\ e-mail: rebioguimaraes@yahoo.com.br \\ ${ }^{2}$ Faculdade de Ciências Integradas do Pontal, Universidade Federal de Uberlândia - UFU, \\ CEP 38408-100, Uberlândia, MG, Brazil \\ e-mail: katiafacure@hotmail.com \\ ${ }^{3}$ Instituto de Química, Universidade Federal de Uberlândia - UFU, CEP 38408-100, Uberlândia, MG, Brazil \\ e-mail: pavanin@ufu.br \\ ${ }^{4}$ Instituto de Biologia, Universidade Federal de Uberlândia - UFU, CEP 38408-100, Uberlândia, MG, Brazil \\ e-mail: gbjacobucci@yahoo.com.br
}

\begin{abstract}
Aim: Veredas and the aquatic and semi-aquatic communities play a key role in watershed protection in the Cerrado Biome. Information about the effects of physical and chemical variables and habitat integrity on benthic communities has been increased in recent years; however, there is no study evaluating the influence of urbanization on macroinvertebrates of Vereda streams. Thus, improving the knowledge of the relationship between abiotic properties and benthic fauna is very important for understanding the functioning of ecological processes and health of aquatic ecosystems. This study investigated the influence of physical and chemical variables on benthic macroinvertebrate communities along a gradient of anthropogenic disturbance in four Vereda streams in Uberlândia (MG), one in a preserved area and three in the urban area; Methods: samplings were collected during the dry and rainy seasons; Results: principal component analysis separated the stream in the preserved area from those in the urban area by having lower values of $\mathrm{BOD}, \mathrm{COD}$, sediment size, conductivity, detergents, $\mathrm{pH}$, deposited solids and total dissolved solids. Pollution sensitive groups (e.g., Ephemeroptera and Trichoptera) were associated to the stream in the preserved area, and more tolerant groups (e.g., Chironomidae and Oligochaeta) had greater abundance in the streams of the urban area. Canonical Correspondence Analysis indicated that dissolved oxygen, conductivity, BOD, oil and grease, and turbidity explained $56 \%$ of the variance in the distribution and abundance of macroinvertebrates; Conclusions: Benthic communities of Vereda streams in urban areas in the Cerrado Biome seem to be highly affected by human activities that increase water organic pollution and sedimentation.
\end{abstract}

Keywords: bioindicators, environmental quality, pollution, Cerrado.

Resumo: Objetivo: Veredas e comunidades aquáticas e semi-aquáticas desempenham importante papel na proteção das bacias hidrográficas no Bioma Cerrado. Informaçōes sobre efeitos de variáveis físico-químicas e da integridade do habitat nas comunidades de macroinvertebrados bentônicos têm aumentado nos anos recentes, entretanto, não há estudos avaliando a influência da urbanização nas comunidades de macroinvertebrados em córregos de veredas. Assim, ampliar o conhecimento da relação entre as variáveis abióticas e fauna bentônica é muito importante para a compreensão do funcionamento dos processos ecológicos e da integridade dos ecossistemas aquáticos. Este estudo investigou a influência de variáveis físicas e químicas nas comunidades de macroinvertebrados bentônicos ao longo de um gradiente de distúrbios antrópicos em quatro córregos de Vereda em Uberlândia (MG); um em uma área preservada e três na área urbana; Métodos: as amostras foram coletadas nas estaçóes seca e chuvosa; Resultados: A análise de componentes principais separou o córrego da área preservada daqueles da área urbana por apresentar menores valores de $\mathrm{DBO}, \mathrm{DQO}$, tamanho do sedimento, condutividade, detergentes, $\mathrm{pH}$, sólidos depositáveis e sólidos totais dissolvidos. Grupos sensíveis à poluiçẫo (e.g., Ephemeroptera 
e Trichoptera) foram associados ao córrego da área preservada e grupos mais tolerantes (Chironomidae e Oligochaeta) tiveram maior abundância nos córregos da área urbana. A Análise de Correspondência Canônica indicou que oxigênio dissolvido, condutividade, DBO, óleos e graxas e turbidez explicaram $56 \%$ da variação na distribuição e abundância de macroinvertebrados; Conclusóes: comunidades bentônicas de córregos de Vereda em áreas urbanas no Bioma Cerrado parecem ser altamente afetadas pelas atividades humanas que aumentam a poluição orgânica da água e a sedimentação.

Palavras-chave: bioindicadores, qualidade ambiental, poluição, Cerrado.

\section{Introduction}

Benthic macroinvertebrates inhabit river beds, lakes and reservoirs and are associated with various types of substrates such as mineral sediments, detritus, macrophytes and filamentous algae (Rosenberg and Resh, 1993). They are essential elements in lentic and lotic trophic webs, participating in the energy flow and nutrient cycling (Whiles and Wallace, 1997). They are also important food resources for fish (Wallace and Webster, 1996) and some insectivorous birds (Ward et al., 1995).

The distribution of aquatic organisms is the result of interactions among their ecological role, the physical conditions that characterize the habitat, and food availability (Merritt and Cummins, 1984). Thus, the community structure of benthic macroinvertebrates depends on a number of factors, namely water quality, type of substrate, particle size of sediment, water flow, sediment organic matter availability, oxygen concentration as well as environmental conditions surrounding the watercourse (Ward et al., 1995; Buss et al., 2004).

Because they reflect environmental changes, benthic macroinvertebrates are often used as indicators of the effects of human activity on water system and provide information on habitat and water quality (Woodcock and Huryn, 2007). The organic enrichment of water caused by both domestic and industrial effluents is a common anthropogenic impact on urban watercourses. This kind of pollution changes physical and chemical characteristics of lotic systems, thus affecting the assemblage of benthic macroinvertebrates (Hynes, 1970; Ward et al., 1995).

The Cerrado, the second largest Brazilian biome occupies $21 \%$ of the country and is considered a hotspot due to its impressive biodiversity and endemism and the accelerated rates of deforestation. The Cerrado is cited in scientific literature as one of the biomes that have the highest species richness of the world and much of this richness has yet to be known (Oliveira-Filho and Medeiros, 2008), including freshwater invertebrates. About $80 \%$ of its natural range was converted to urban occupation or agricultural activities, involving, among many consequences, degradation of water sources. The clearing of native vegetation reaches, in most cases, the forests adjacent to watercourses which, in this biome, occupy areas of good soil (Ribeiro et al., 2001). This vegetation is important to maintain the ecological equilibrium of aquatic environments, minimizing erosion and sediment deposition.

Among the various physiognomies associated with Cerrado, the Veredas are very widespread in this biome, and they are highlighted because they are closely related to waterways. The Veredas are wetlands, with hydromorphic soils that can be very rich in organic matter (Wantzen et al., 2006). They occur in small valleys with distinctive hydrophytic vegetation (Lima 1996), including tree-shrub species, dominated by the buriti palm (Mauritia vinifera Mart.), and several grass species (Oliveira and Marquis, 2002).

Veredas and the aquatic and semi-aquatic communities play a key role in watershed protection. They minimize erosion and provide food, living space, breeding places and escape routes to local fauna that depends directly or indirectly on the plants (Oliveira and Marquis, 2002).

Information about the effects of physical and chemical variables and habitat integrity on benthic communities in Brazil has been increased in recent years (Callisto et al., 2001; Marques and Barbosa, 2001; Buss et al., 2002; Buss et al., 2004; Bispo et al., 2004; Bispo et al., 2006; Buckup et al., 2007; Couceiro et al., 2007; Hepp and Santos, 2009). However, there is no study evaluating the influence of urbanization on macroinvertebrates of Vereda streams in the Cerrado Biome.

Thus, improving the knowledge of the relationship between abiotic properties and benthic fauna is very important for understanding the 
functioning of ecological processes and integrity of aquatic ecosystems. The data generated are particularly important for planning interventions to preserve or manage water systems, to ensure its biological integrity or, in other words, the system's ability to maintain its natural biodiversity and essential ecological processes for their perfect functioning.

In this context, this study aimed to characterize the distribution patterns and seasonal variation of benthic macroinvertebrate communities in streams from an urban area of Central Brazil, and to evaluate the influence of key environmental factors on these communities.

\section{Material and Methods}

\subsection{Study site}

The study was performed in first order streams of the Uberabinha river basin, with about $2000 \mathrm{~km}^{2}$, in the Triângulo Mineiro region, Minas Gerais state, Brazil. The local climate is tropical and, according to the climate classification of Köppen is Aw type, megatermic, with summer rains and winter drought
(Köeppen, 1948). Uberlândia is located in a climate region with annual mean temperatures ranging from 19 to $27^{\circ} \mathrm{C}$ and average rainfall around $1500 \mathrm{~mm}$. year $^{-1}$ (Silva and Assunção, 2004).

Four streams (Cabeceira do Lageado, Buritizinho, Lobo and Bons Olhos) located in different regions of the urban area of Uberlândia $\left(55^{\circ} 08^{\prime} 18^{\prime \prime} \mathrm{S}\right.$ and $\left.48^{\circ} 16^{\prime} 37^{\prime \prime} \mathrm{W}\right)$ were selected (Figure 1). The streams have width varying from 1.5 to $2.5 \mathrm{~m}$ and depth ranging from 0.15 to $0.80 \mathrm{~cm}$. All stream headwaters are situated in Vereda environments with predominantly muddy sandy substrate. Although they are located in permanent preservation areas (APPs), in urban areas in general and specifically in Uberlândia, degradation of Veredas is recurrently causing profound environmental disturbances (Schiavini and Araújo, 1989).

For better representation of the streams three sampling sites were established in each stream, one near the headwaters (P1), another near the mouth (P3) and another intermediate between these (P2). The headwaters of the Lageado stream (Stream 1) are located in an ecological reserve (Reserva do Clube de Caça e Pesca) about 10 km from Uberlândia city

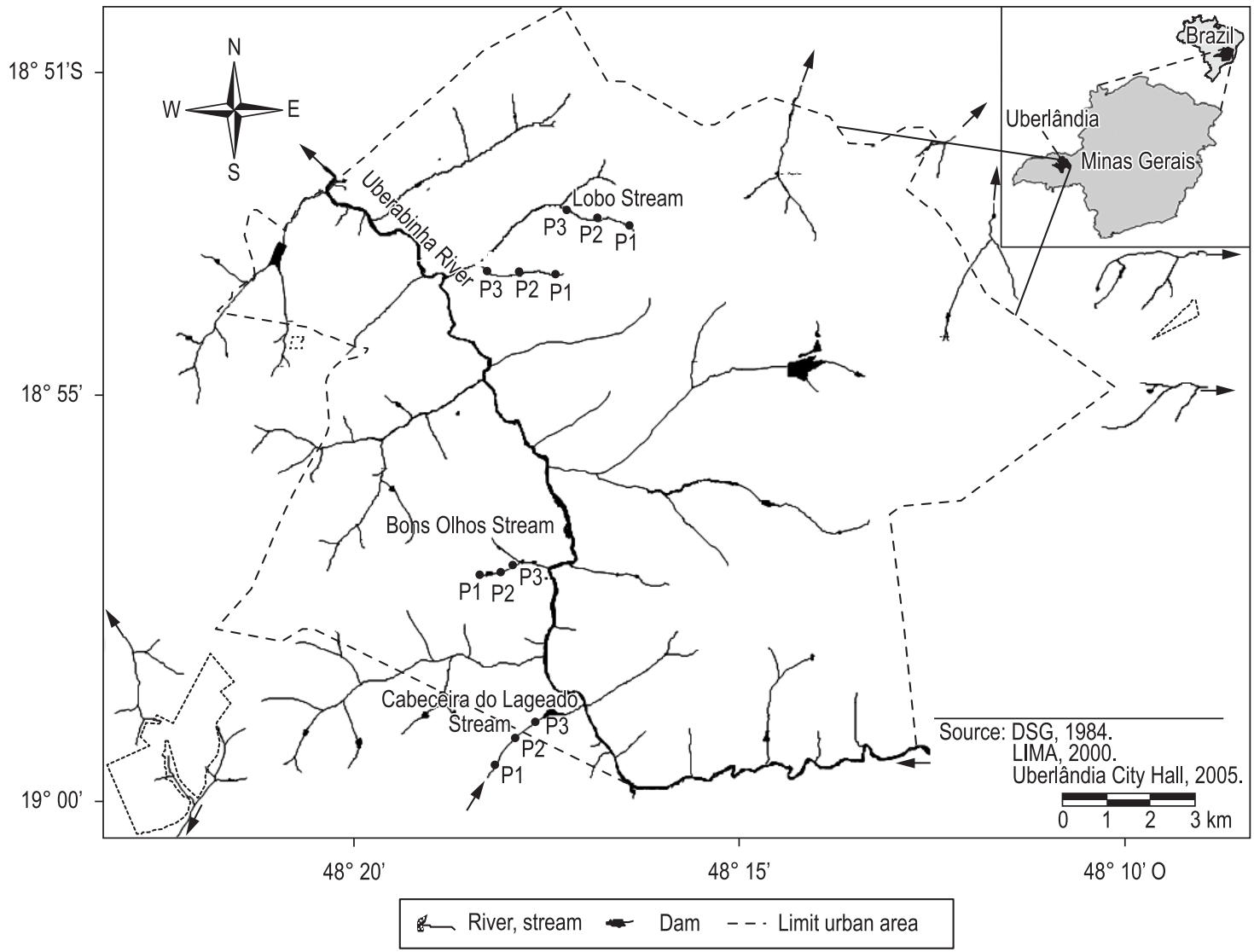

Figure 1. Uberabinha River Basin in the urban area of Uberlândia - MG and location of the studied streams (S1 Stream 1 - Cabeceira do Lageado; S2 Stream 2 - Buritizinho; S3 Stream 3 - Lobo and S4 Stream 4 - Bons Olhos) and sampling sites (P1; P2; P3). 
center. The Buritizinho (Stream 2), Lobo (Stream 3) and Bons Olhos (Stream 4) streams are directly inserted into the urbanized area of Uberlândia and subject to various kinds of anthropogenic impacts mainly due to the loss of vegetation along the banks of streams and inflow of domestic sewage and garbage.

\subsection{Sampling of benthic macroinvertebrates}

Sampling of benthic macroinvertebrates was performed in rainy (March/2007) and dry (July/2007) seasons. At each sampling site of the streams, three substrate sub-samples were randomly collected, using a Surber collector of $900 \mathrm{~cm}^{2}$ and of $0.25 \mathrm{~mm}$ mesh size. The three sub-samples of each site were pooled and represented one sample, totaling 12 samples per sampling period.

The samples were packed in plastic bags, labeled, fixed in a $10 \%$ formalin solution, and transported to the laboratory for processing. The collected material was washed on a mesh of $0.25 \mathrm{~mm}$, and sorted in Petri dishes, using a stereomicroscope. The benthic macroinvertebrates were identified to the family level - except the molluscs (Class), annelids (Subclass), nematodes (Phylum) and isopods (Order) - using specific identification keys (Wiggins, 1977; Merritt and Cummins, 1984; Righi, 2002).

\subsection{Physical and chemical variables of water and sediment}

In each sampling period, the sites were sampled three times (two weeks before macroinvertebrates sampling, simultaneously with macroinvertebrate sampling and two weeks after macroinvertebrate sampling) to evaluate physical and chemical variables of water and sediment. Water samples were collected in triplicate with amber bottles with $1.5 \mathrm{~L}$ capacity, at $20 \mathrm{~cm}$ water depth. The samples were fixed and packed using techniques and methods described by the American Public Health Association (APHA, 1995).

Except for the measurement of water temperature, which was performed with a mercury thermometer, in situ, the other physical and chemical variables were analyzed in the laboratory. The conductivity and $\mathrm{pH}$ were measured using a digital conductivity meter (Digimed DM-32) and a digital pHmeter (Digimed DMPH), respectively. The turbidity was determined by nephelometric method (using a digital turbidimeter HD114) and Dissolved Oxygen by Winkler method. Biochemical oxygen demand (BOD5), chemical oxygen demand (COD), oil and grease concentration, total dissolved solids (TDS), deposited solids and detergents were determined according to Macêdo (2003). The suspended solids (Greenberg et al., 2005) and concentrations of manganese $(\mathrm{Mn})$ and iron $(\mathrm{Fe})$ (Pregnolato and Pregnolato, 1985) were also determined. One sediment sample was collected from each sampling site in rainy and dry periods to assess organic matter content (Pregnolato and Pregnolato, 1985) and particle size, totaling 12 samples per period.

\subsection{Data analysis}

Patterns of spatial and seasonal variation in benthic community composition and abundance and in environmental variables were described using Correspondence Analysis (CA) and Principal Component Analysis (PCA), respectively, performed with FITOPAC 1.5 (Shepherd, 2004). To assess the environmental variables explaining most of the variation on the distribution of macroinvertebrates, a Canonical Correspondence Analysis (CCA) was performed using the forward selection procedure in CANOCO 4.5 (Terbraak and Smilauer, 2002). Multicollinearity was assessed by examining the Variance Inflation Factor (VIF). Only significant non-redundant variables were included in the final model. Abundances, turbidity, oil and grease, dissolved oxygen, sedimentable solids, suspended solids, Mn, BOD and organic matter had positively skewed distributions and were log-transformed. In addition, all environmental variables were standardized to the same scale (values between zero and one) before analyses. For PCA and CCA analysis, Chironomidae was separated from "Other Diptera”, Hydrophilidae from "Other Coleoptera”, and Hydropsychidae from "Other Trichoptera". These families represent important groups both numerically and ecologically (more tolerant to pollution). The category "Other invertebrates" includes representatives of Nematoda, Isopoda, Lepidoptera and Hemiptera.

\section{Results}

The values of physical and chemical water parameters are indicated in Figure 2. The $\mathrm{pH}$ values were recorded in a slightly acidic range, with lower values in the dry season. For conductivity, lower values were found in Stream 1, higher values in Streams 2 and 3, and intermediate values in stream 4. In the dry season, the values of dissolved oxygen and turbidity were low in all streams, while in the rainy season higher values were recorded. The values of $\mathrm{BOD}, \mathrm{COD}$ and detergents were higher in Stream 2 and lower in other streams. A wide 


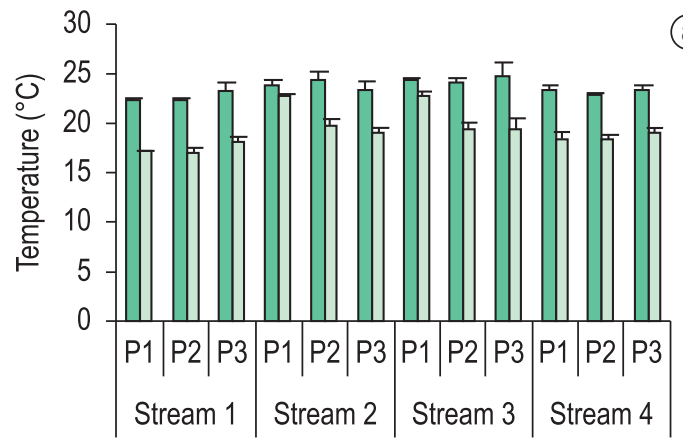

(a)
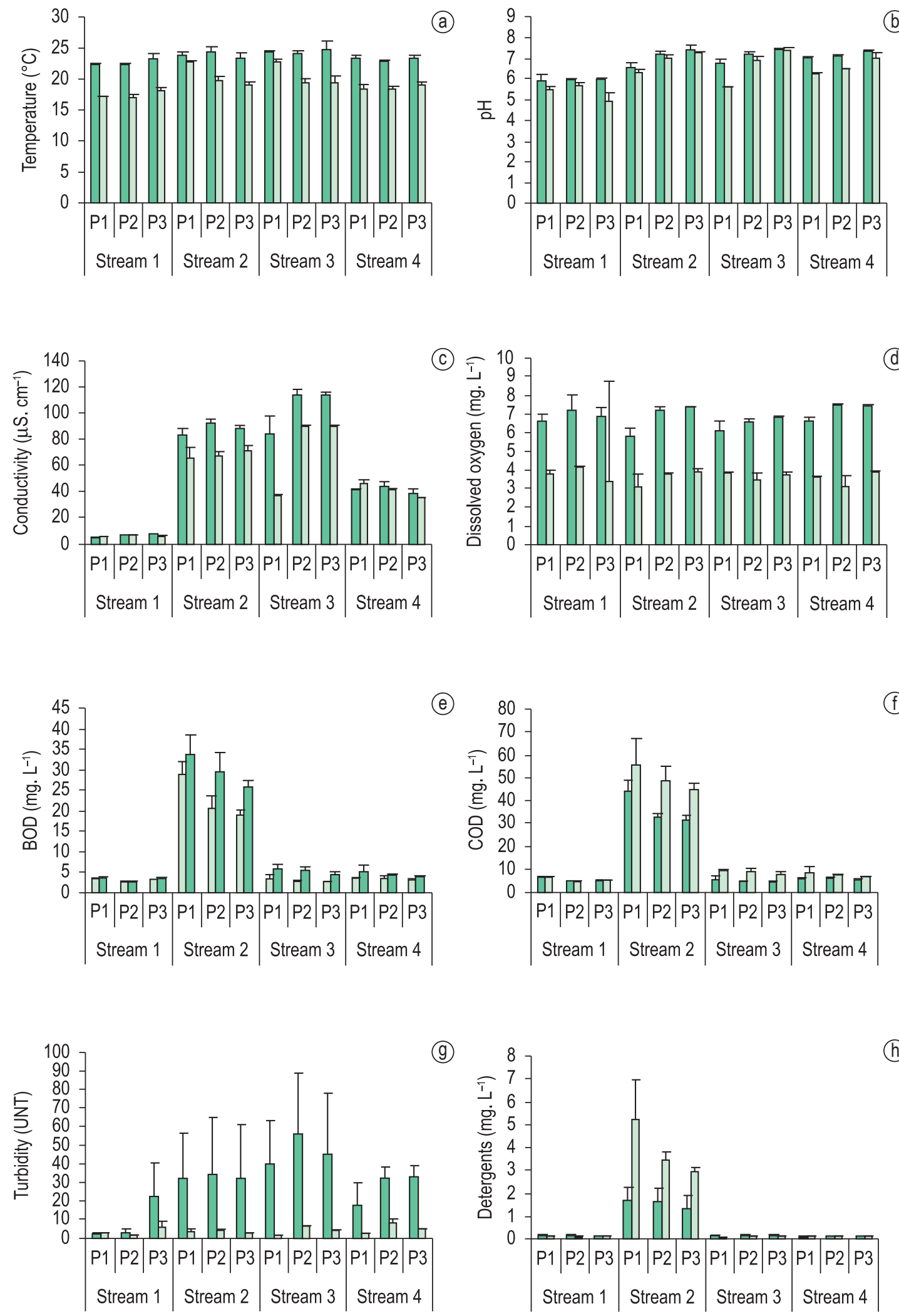

(9)

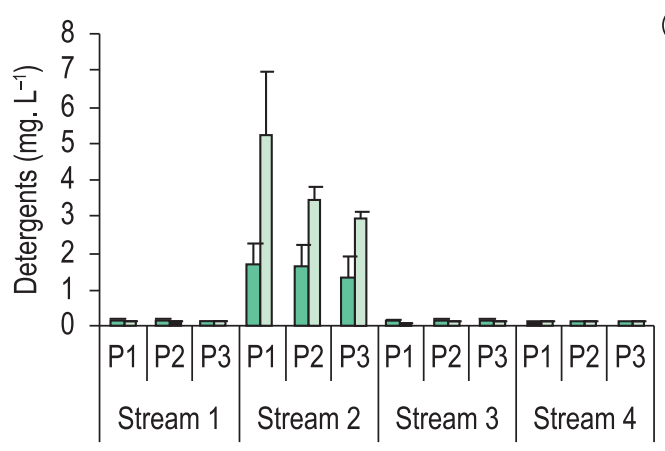

$\square$ Rainy season $\square$ Dry season

Figure 2 (a-h). Mean values and standard error of the physical and chemical variables of water from Streams 1, 2, 3 and 4, Uberlândia - MG, 2007. N = 3 for site sampled. Rainy Season, Dry Season. a) Temperature; b) pH; c) conductivity; d) dissolved oxygen; e) BOD; f) COD; g) turbidity; h) detergent. 


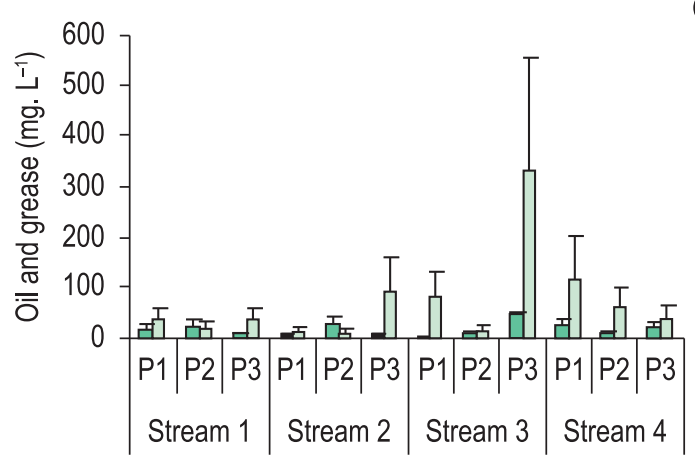

(i)

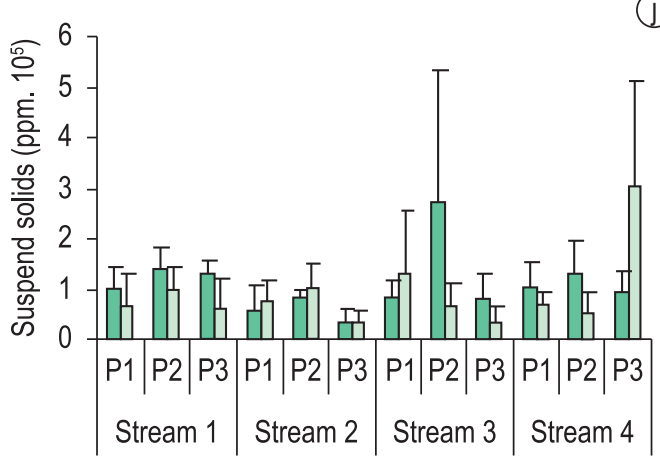

(K)
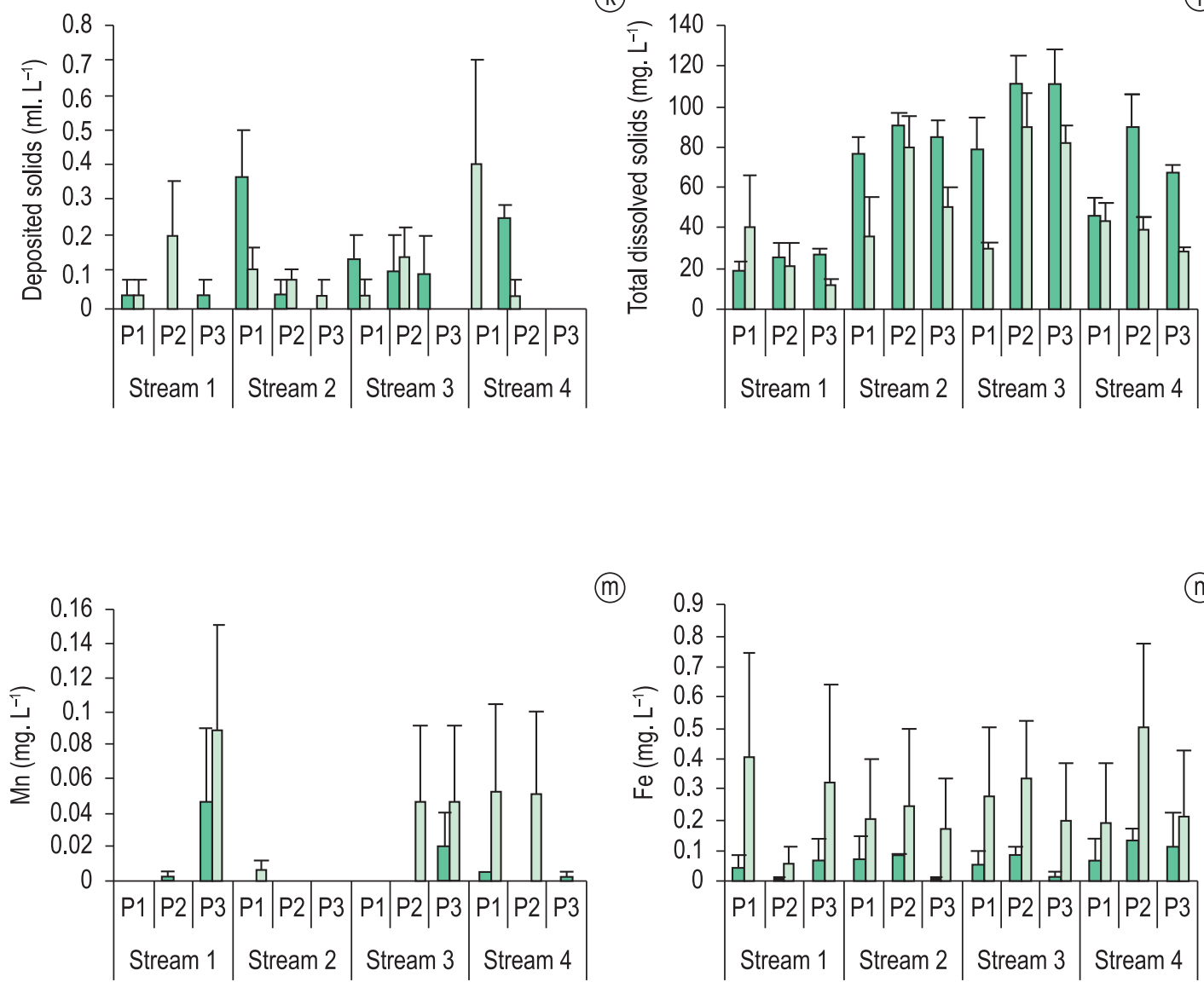

(I)

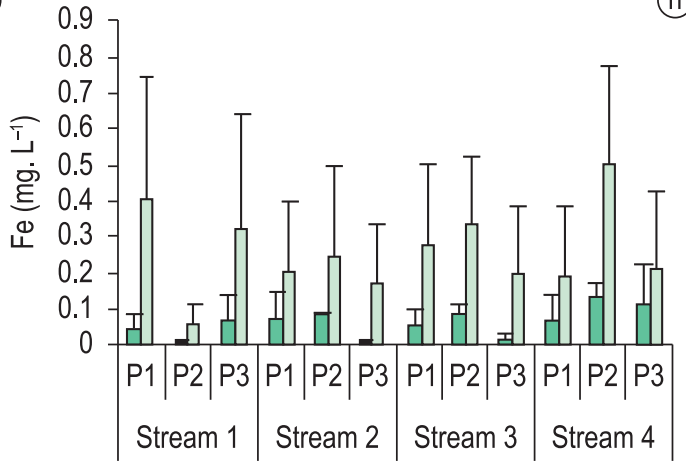

$\square$ Rainy season $\square$ Dry season

Figure 2 (i-n). Mean values and standard error of the physical and chemical variables of water from Streams 1, 2, 3 and 4, Uberlândia - MG, 2007. N = 3 for site sampled. Rainy Season, Dry Season. i) oil and grease; j) suspended solids; k) sedimentable solids; l) total dissolved solids; m) Manganese (Mn); n) Iron (Fe). P = Sample sites.

variation between and within each stream was found for sedimentable solids and higher values of total dissolved solids in Streams 2, 3 and 4. Concerning the sediment size there was a predominance of smaller grains in both seasons in Streams 1 and 4
(Figure 3). The highest values of organic matter in the sediment were found in Stream 1 (Figure 4).

The first two axes of PCA explained 51.45\% of the variance in environmental variables data (Figure 5). The most important variables in axis 1 

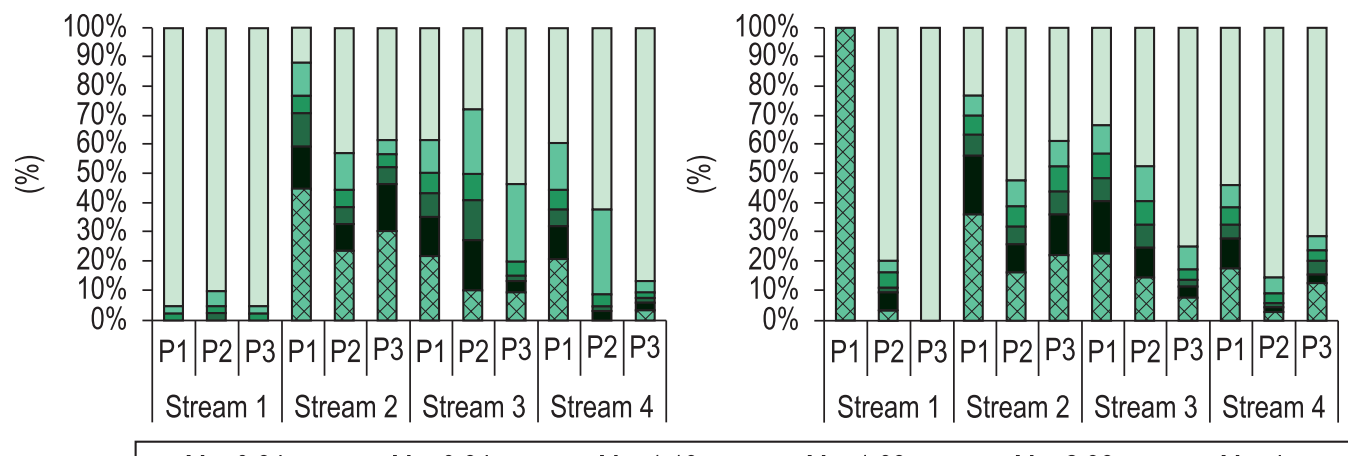

$\square \mathrm{M}<0.84 \mathrm{~mm} \quad \square \mathrm{M}=0.84 \mathrm{~mm} \square \mathrm{M}=1.19 \mathrm{~mm} \quad \square \mathrm{M}=1.68 \mathrm{~mm}$

$M=2.38 \mathrm{~mm} \quad \Delta \mathrm{M}=4 \mathrm{~mm}$

Figure 3. Granulometric composition of the sediment at the sampling sites of Streams 1, 2, 3 and 4, Uberlândia - MG, 2007. a) Wet season; b) dry season. P = sampling sites.

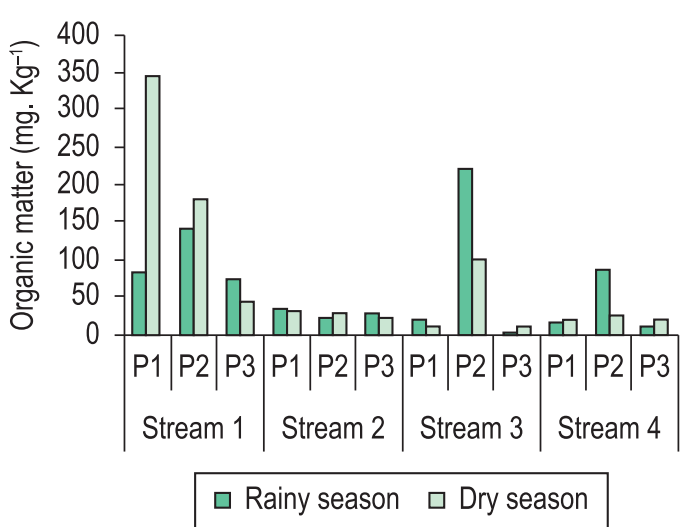

Figure 4. Values of the concentration of organic matter in sediments from Streams 1, 2, 3 and 4, Uberlândia - MG, 2007.

were total dissolved solids, conductivity, particle size and $\mathrm{pH}$. In axis 2 , the most important variables were dissolved oxygen, turbidity and temperature, all of them with negative loadings and iron with positive loadings. Detergents, BOD and COD were strongly correlated and were important in the two axes (Table 2).

A plot of sample scores on the first two PCA axes showed little overlap between the four streams (Figure 5). Stream 1 differed from Stream 2 by the higher amount of organic matter and lower values of BOD, sediment size, conductivity, detergents, $\mathrm{pH}$, deposited solids and total dissolved solids. Streams 3 and 4 had intermediate values for these variables. In this analysis, it was also possible to detect seasonal differences in oxygen concentration and turbidity, which were higher in rainy season samples and the amount of iron and oil and grease, which were higher in the dry season. Thus, axis 1 describes a gradient of environmental quality and axis 2 a gradient of seasonality.
Stream 1 had a greater representation of Ephemeroptera, Plecoptera and Trichoptera (EPTs), followed by Stream 4 and Stream 2. EPTs were not recorded in Stream 3. The abundance of Chironomidae was high in all streams, while Oligochaeta abundance was low in Streams 1 and 4 and high in Streams 2 and 3. Molluscs did not occur in the headwaters of the Stream 1 (Table 1).

The first CA axis explained $44.25 \%$ of variance in the abundance data of benthic macroinvertebrate taxa and indicated the existence of a gradient with the sampling sites of Stream 1 at one end and of Stream 2 in another. Stream 1 was separated from the others because it had a higher abundance of Ephemeroptera, "Other Coleoptera", Trichoptera and Hemiptera, and absence of Hirudinea, Hydrophilidae, Mollusca and Collembola. Hydropsychidae were absent in Stream 3 and rare in Stream 4 and Odonata were rare in the Stream 2. Chironomidae, Oligochaeta and Other Diptera were more equally distributed throughout the gradient (Figure 6).

The environmental variables temperature, chemical oxygen demand (COD), total dissolved solids (TDS), detergents, and iron (Fe) had VIF greater than 20 and were excluded from the final CCA. Among the eleven remaining variables, conductivity $(\mathrm{F}=10.065, \mathrm{p}=0.0001)$, dissolved oxygen $(\mathrm{F}=2.263, \mathrm{p}=0.0201)$, turbidity $(\mathrm{F}=2.237$, $\mathrm{p}=0.0168), \operatorname{BOD}(\mathrm{F}=2.144, \mathrm{p}=0.0300)$ and oil and grease $(\mathrm{F}=2.335, \mathrm{p}=0.0133)$ were significantly correlated with composition and abundance of macroinvertebrates. Together, these variables explained $56 \%$ of the variance in benthic communities. Ephemeroptera, "Other Coleoptera", "Other Trichoptera", Hemiptera, Odonata, Hydropsychidae and "Other Diptera" were most abundant in sites with higher concentration 
Table 1. Taxonomic composition and abundance of macroinvertebrates in rainy $(\mathrm{R})$ and dry (D) periods in Streams 1 (Cabeceira do Lageado), 2 (Buritizinho), 3 (Lobo) and 4 (Bons Olhos), Uberlândia - MG, 2007.

\begin{tabular}{|c|c|c|c|c|c|c|}
\hline \multirow[t]{2}{*}{ Taxa } & \multicolumn{5}{|c|}{ Abundance } & \multirow[t]{2}{*}{ Total } \\
\hline & Period & Stream 1 & Stream 2 & Stream 3 & Stream 4 & \\
\hline \multirow[t]{2}{*}{ Nematoda } & $R$ & 1 & 17 & 14 & 5 & 37 \\
\hline & D & 2 & 4 & 13 & 6 & 25 \\
\hline \multicolumn{7}{|l|}{ Mollusca } \\
\hline \multirow[t]{2}{*}{ Bivalvia } & $\mathrm{R}$ & - & - & - & - & \\
\hline & D & - & - & 7 & 83 & 90 \\
\hline \multirow[t]{2}{*}{ Gastropoda } & $\mathrm{R}$ & - & 70 & 28 & 3 & 101 \\
\hline & D & - & 46 & 32 & 63 & 141 \\
\hline \multicolumn{7}{|l|}{ Annelida } \\
\hline \multirow[t]{2}{*}{ Oligochaeta } & $R$ & 8 & 5027 & 2618 & 29 & 7707 \\
\hline & D & 94 & 412 & 10918 & 380 & 11853 \\
\hline \multirow{2}{*}{ Hirudinea } & $\mathrm{R}$ & - & 14 & - & 8 & 22 \\
\hline & D & - & 154 & - & 69 & 223 \\
\hline \multirow{2}{*}{ Isopoda } & $\mathrm{R}$ & - & - & 3 & - & 3 \\
\hline & D & - & - & - & - & \\
\hline \multicolumn{7}{|l|}{ Diptera } \\
\hline \multirow[t]{2}{*}{ Ceratopogonidae } & $\mathrm{R}$ & 1 & 10 & 3 & 10 & 54 \\
\hline & D & 22 & 15 & 6 & 98 & 274 \\
\hline \multirow[t]{2}{*}{ Chaoboridae } & $\mathrm{R}$ & - & - & - & - & - \\
\hline & D & 3 & - & - & - & 3 \\
\hline \multirow[t]{2}{*}{ Chironomidae } & $R$ & 202 & 9742 & 8496 & 1124 & 20725 \\
\hline & D & 992 & 2730 & 288 & 4398 & 10418 \\
\hline \multirow[t]{2}{*}{ Culicidae } & $R$ & - & - & - & - & 2 \\
\hline & D & 3 & - & 4 & - & 11 \\
\hline \multirow[t]{2}{*}{ Empididae } & $\mathrm{R}$ & 1 & 2 & 2 & 1 & 6 \\
\hline & D & 15 & - & 2 & 87 & 105 \\
\hline Ephydridae & $\mathrm{R}$ & - & - & - & - & \\
\hline & D & - & - & 2 & 1 & 3 \\
\hline Psychodidae & $\mathrm{R}$ & - & - & 1 & 1 & 2 \\
\hline & D & - & - & 13 & 4 & 18 \\
\hline Simuliidae & $\mathrm{R}$ & 1 & 1 & - & 3 & 5 \\
\hline & D & 14 & 1 & 1 & 136 & 152 \\
\hline Tabanidae & $\mathrm{R}$ & 2 & - & 3 & - & 5 \\
\hline & D & 2 & - & 2 & 22 & 30 \\
\hline Tipulidae & $\mathrm{R}$ & - & - & 1 & - & 6 \\
\hline & D & - & - & - & 22 & 23 \\
\hline Collembola & & & & & & \\
\hline Entomobryidae & $\mathrm{R}$ & - & 1 & 4 & 1 & 6 \\
\hline & D & 1 & 2 & 2 & 5 & 10 \\
\hline Isotomidae & $\mathrm{R}$ & - & - & - & 5 & 5 \\
\hline & D & - & 4 & 2 & - & 6 \\
\hline Sminthuridae & $\mathrm{R}$ & - & - & - & 2 & 2 \\
\hline & D & - & - & - & - & \\
\hline Coleoptera & & & - & - & & \\
\hline Dytiscidae & $\mathrm{R}$ & - & - & - & - & 1 \\
\hline & D & 6 & - & - & - & 1 \\
\hline Elmidae & $\mathrm{R}$ & 14 & - & 1 & - & 16 \\
\hline & D & 69 & - & 1 & 3 & 74 \\
\hline Gyrinidae & $\mathrm{R}$ & 1 & - & - & - & 2 \\
\hline & D & - & - & - & - & \\
\hline Hydrophilidae & $\mathrm{R}$ & - & 146 & 8 & 1 & 155 \\
\hline & D & 3 & 61 & 1 & 114 & 179 \\
\hline Psephenidae & $\mathrm{R}$ & - & - & - & - & \\
\hline & D & 1 & - & - & - & 1 \\
\hline Staphilinidae & $\mathrm{R}$ & - & - & - & - & \\
\hline & D & 1 & - & - & - & 1 \\
\hline
\end{tabular}


Table 1. Continued...

\begin{tabular}{|c|c|c|c|c|c|c|}
\hline \multirow[t]{2}{*}{ Taxa } & \multicolumn{5}{|c|}{ Abundance } & \multirow[t]{2}{*}{ Total } \\
\hline & Period & Stream 1 & Stream 2 & Stream 3 & Stream 4 & \\
\hline \multicolumn{7}{|l|}{ Ephemeroptera } \\
\hline \multirow[t]{2}{*}{ Baetidae } & $\mathrm{R}$ & 8 & - & - & - & 45 \\
\hline & D & 3 & - & - & - & 69 \\
\hline \multirow[t]{2}{*}{ Caenidae } & $\mathrm{R}$ & 1 & - & - & - & 13 \\
\hline & D & 2 & - & - & - & 46 \\
\hline \multirow[t]{2}{*}{ Euthyplociidae } & $\mathrm{R}$ & - & - & - & - & \\
\hline & D & 1 & - & - & - & 18 \\
\hline \multirow[t]{2}{*}{ Leptohyphidae } & $\mathrm{R}$ & 3 & - & - & - & 3 \\
\hline & D & 70 & - & - & - & 70 \\
\hline \multirow[t]{2}{*}{ Leptophebiidae } & $\mathrm{R}$ & 1 & - & - & - & 15 \\
\hline & D & 23 & - & - & - & 81 \\
\hline \multicolumn{7}{|l|}{ Hemiptera } \\
\hline \multirow[t]{2}{*}{ Pleidae } & $\mathrm{R}$ & 1 & - & - & - & 1 \\
\hline & D & - & - & - & - & \\
\hline \multirow[t]{2}{*}{ Hebridae } & $\mathrm{R}$ & - & - & - & - & \\
\hline & D & 1 & - & - & - & 1 \\
\hline \multirow[t]{2}{*}{ Veliidae } & $\mathrm{R}$ & - & - & - & - & \\
\hline & D & - & - & - & 2 & 2 \\
\hline \multirow[t]{2}{*}{ Cicadellidae } & $\mathrm{R}$ & 3 & 2 & 1 & - & 6 \\
\hline & D & - & - & - & - & \\
\hline \multirow[t]{2}{*}{ Naucoridae } & $\mathrm{R}$ & - & - & - & - & \\
\hline & D & 4 & - & 2 & - & 8 \\
\hline \multicolumn{7}{|l|}{ Lepidoptera } \\
\hline \multirow[t]{2}{*}{ Pyralidae } & $\mathrm{R}$ & - & - & - & 1 & 2 \\
\hline & D & 12 & - & - & - & 13 \\
\hline \multicolumn{7}{|l|}{ Odonata Anisoptera } \\
\hline Libellulidae & $\mathrm{R}$ & 2 & 6 & 16 & 3 & 38 \\
\hline & D & 3 & - & 15 & 2 & 29 \\
\hline Gomphidae & $\mathrm{R}$ & 1 & - & - & - & 1 \\
\hline & D & - & - & - & - & \\
\hline Odonata Zygoptera & & & & & & \\
\hline Coenagrionidae & $\mathrm{R}$ & 1 & - & - & - & 6 \\
\hline & D & 3 & - & 1 & 25 & 35 \\
\hline Calopterygidae & $\mathrm{R}$ & 1 & - & - & - & 1 \\
\hline & D & 2 & - & - & - & 2 \\
\hline Plecoptera & & - & - & - & - & \\
\hline Perlidae & $\mathrm{R}$ & - & - & - & - & \\
\hline & D & 1 & - & - & - & 1 \\
\hline Trichoptera & & & & & & \\
\hline Hydroptilidae & $\mathrm{R}$ & 5 & 14 & - & - & 46 \\
\hline & D & 1 & - & - & 1 & 4 \\
\hline Hydropsychidae & $\mathrm{R}$ & 20 & 38 & - & 21 & 88 \\
\hline & D & 85 & 29 & - & 11 & 133 \\
\hline Leptoceridade & $\mathrm{R}$ & 5 & - & - & - & 5 \\
\hline & D & 1 & - & - & - & 1 \\
\hline Odontoceridae & $\mathrm{R}$ & 10 & - & - & 2 & 15 \\
\hline & D & 5 & - & - & 3 & 14 \\
\hline Philopotamidae & $\mathrm{R}$ & 1 & - & - & - & 1 \\
\hline & D & 22 & - & - & - & 22 \\
\hline & & 1760 & & & & \\
\hline Total abundance & $\mathrm{R}$ & 293 & 1576 & 11199 & 1236 & 29148 \\
\hline & D & 1467 & 3458 & 11312 & 5557 & 24190 \\
\hline Richness & $\mathrm{R}$ & 28 & 13 & 15 & 16 & 36 \\
\hline & D & 32 & 11 & 19 & 22 & 42 \\
\hline
\end{tabular}


Table 2. Component loadings for the first two principal components on the physical and chemical water variables from Streams 1, 2, 3 and 4, Uberlândia - MG, 2007. In bold the largest component loadings in each axis.

\begin{tabular}{lcc}
\hline \multicolumn{1}{c}{ Variables } & Axis 1 & Axis 2 \\
\hline $\mathrm{pH}$ & $\mathbf{0 . 3 2 6}$ & -0.136 \\
Temperature & 0.273 & $-\mathbf{0 . 3 2 2}$ \\
Conductivity & $\mathbf{0 . 3 5 3}$ & -0.018 \\
Turbidity & 0.027 & $-\mathbf{0 . 3 4 4}$ \\
Total dissolved solids & $\mathbf{0 . 3 2 5}$ & -0.183 \\
Oil and grease & -0.077 & 0.132 \\
Dissolved oxygen & 0.139 & $-\mathbf{0 . 4 4 8}$ \\
Suspended solids & -0.045 & -0.243 \\
Deposited solids & 0.106 & 0.027 \\
Detergents & $\mathbf{0 . 3 1 4}$ & $\mathbf{0 . 3 0 8}$ \\
BOD & $\mathbf{0 . 3 3 2}$ & $\mathbf{0 . 3 1 4}$ \\
COD & $\mathbf{0 . 3 3 0}$ & $\mathbf{0 . 3 1 8}$ \\
Mn & -0.237 & 0.152 \\
Fe & -0.172 & $\mathbf{0 . 3 2 6}$ \\
Organic matter & -0.159 & -0.075 \\
Grain size of the sediment & $\mathbf{0 . 3 4 3}$ & 0.118 \\
\hline
\end{tabular}

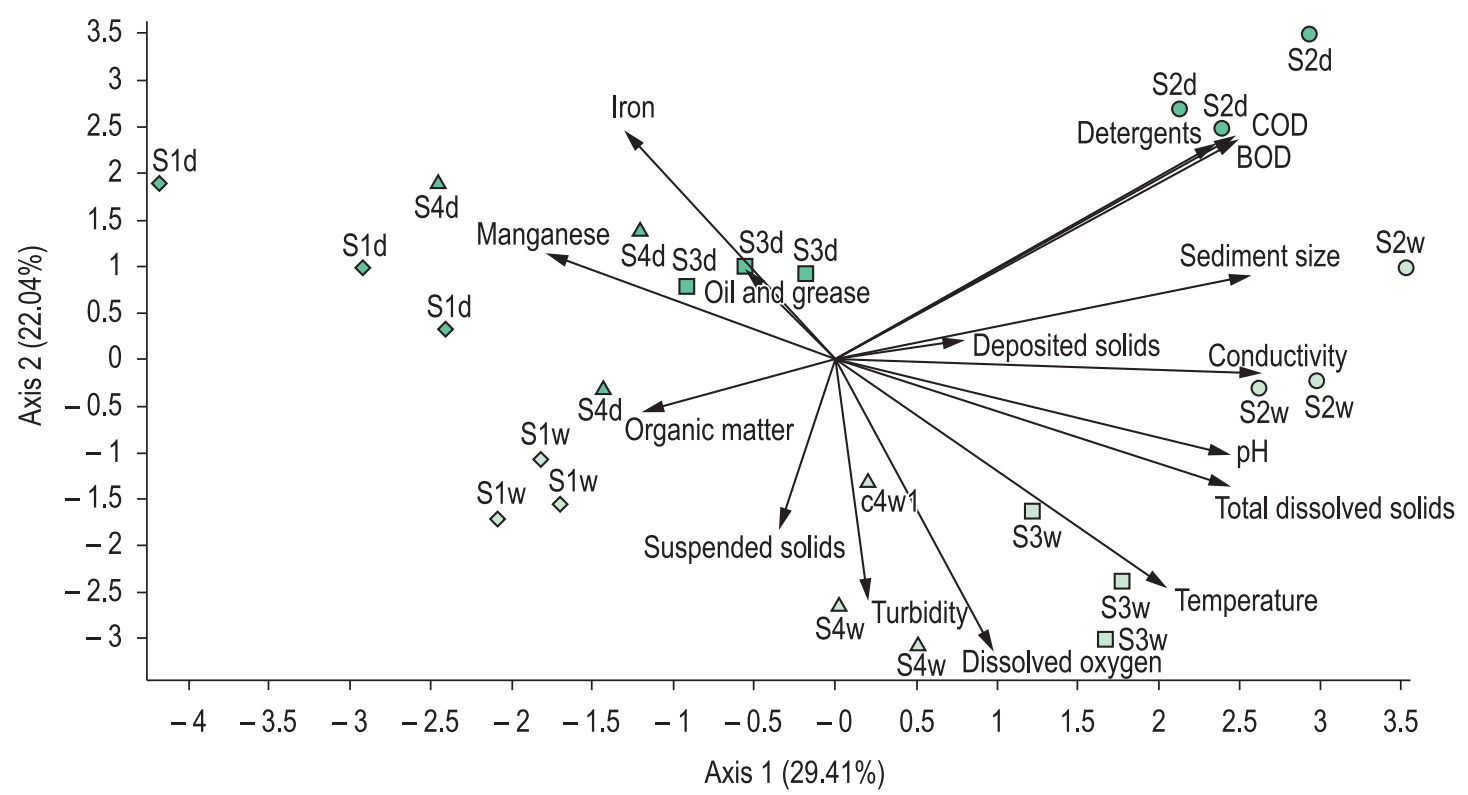

Figure 5. Ordination diagram of the sampling sites by Principal Component Analysis (PCA), considering the physical and chemical variables of water from Streams 1, 2, 3 and 4, Uberlândia - MG, 2007. S - Stream (1, 2, 3 and 4), w - wet season, $d$ - dry season.

of dissolved oxygen and lower conductivity. In contrast, Hydrophilidae, Hirudinea, Mollusca and Oligochaeta occurred in sites with higher values of BOD. Hydrophilidae and Hirudinea were also associated with high amounts of oil and grease and Collembola with higher turbidity (Figure 7).

\section{Discussion}

The seasonal differences in dissolved oxygen concentration and turbidity were expected, since an increase in water movement occurs in the rainy season, favoring oxygenation, and also a higher erosion rate of soil particles from drainage areas, resulting in a great amount of suspended solids and the consequent decrease in water transparency (Maier, 1987). The higher concentrations of iron (Fe) and oil and grease in the dry season may be related to the long periods of drought in this season. The decrease of water discharge probably influences the concentration of these components.

The separation of Stream 2 sites from Stream 1 sites in the PCA was due to its higher values of $\mathrm{BOD}, \mathrm{COD}$, conductivity, $\mathrm{pH}$ and detergents. High values of $B O D$ and $C O D$ in streams indicate 


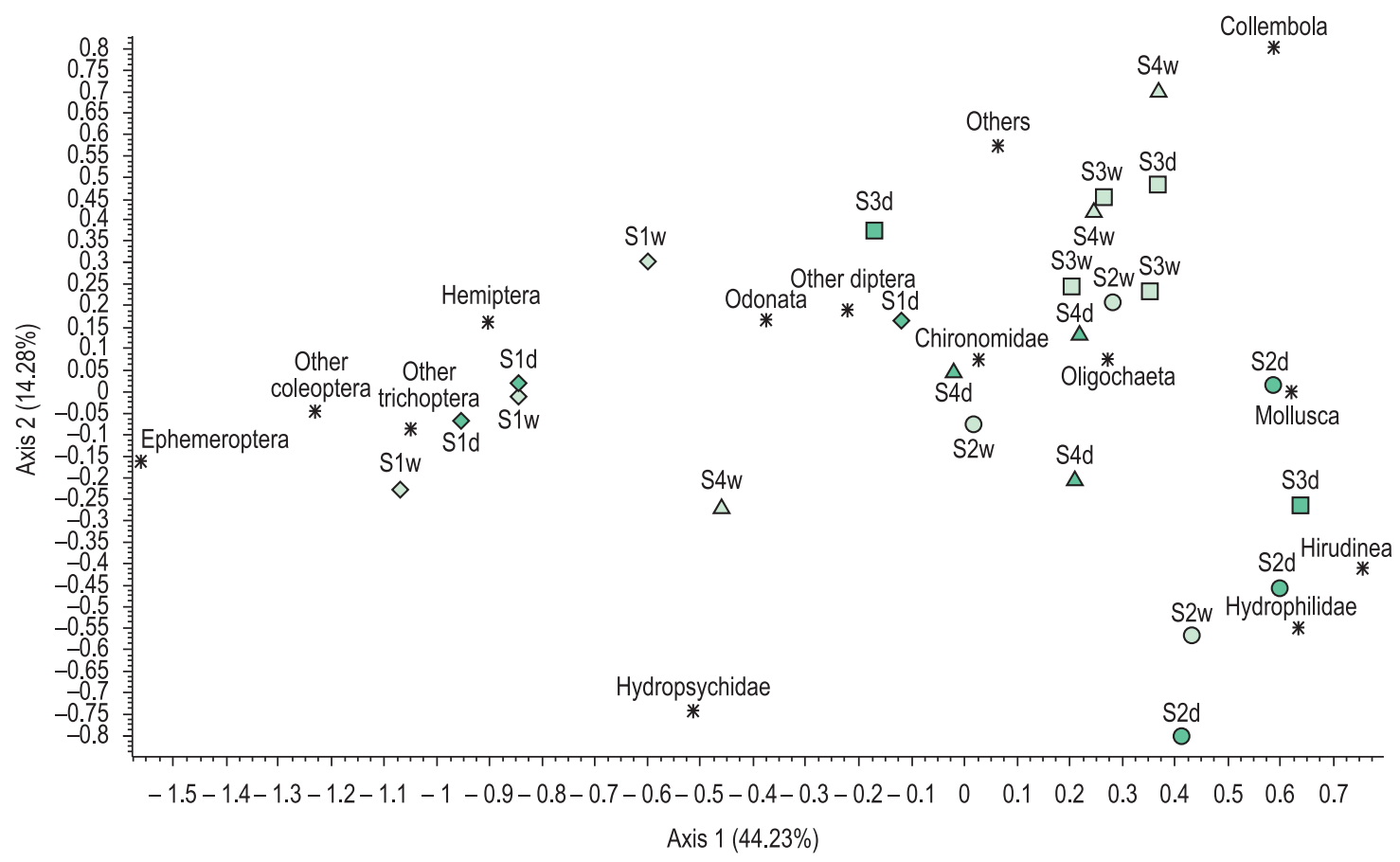

Figure 6. Ordination diagram of sampling sites by Correspondence Analysis (CA), considering the abundance of taxa in Streams 1, 2, 3 and 4, Uberlândia - MG, 2007 S - Stream (1, 2, 3 and 4), w - rainy d - dry season.

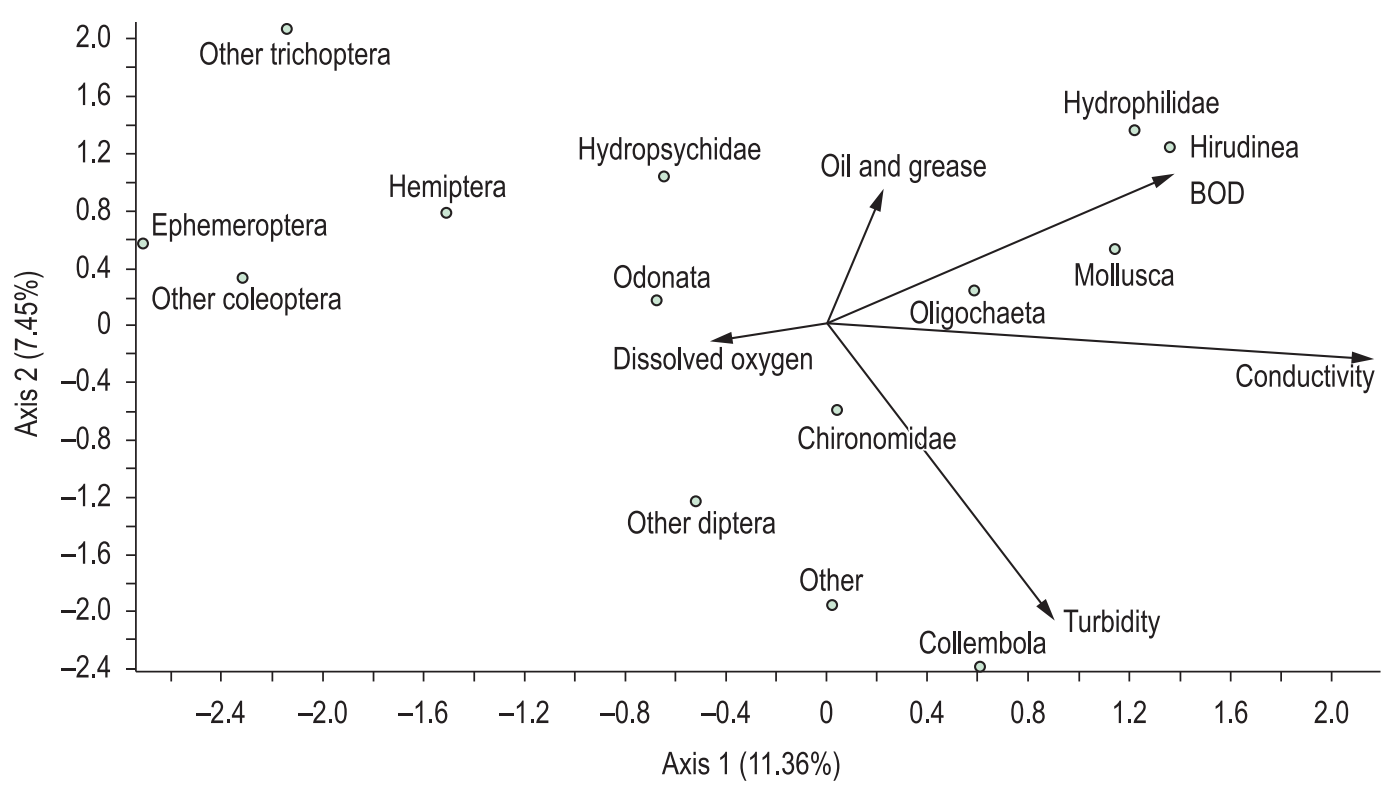

Figure 7. Ordination Diagram of the first two axes of Canonical Correspondence Analysis (CCA) for benthic macroinvertebrates taxa and physical and chemical variables of water and sediment present in Streams 1, 2, 3 and 4, Uberlândia - MG, 2007.

organic contamination probably originated from domestic sewage (Valente et al., 1997). Similarly, high values of conductivity are an indirect measure of the concentration of pollutants. Since conductivity is a numerical expression of the capacity of water to conduct electric current, thus depending on the ionic concentrations and temperature, it indicates the amount of existing salts in the water column (Wetzel, 1983). Detergents, which probably also come from sewage have phosphorus in their composition, which in excess leads to water eutrophication (Valente et al., 1997). Thus, according to these variables, the streams studied appear to differ in their status of environmental 
quality, with Stream 1 showing better water quality. Stream 2 is very impacted and Streams 3 and 4 are in an intermediate environmental situation.

This trend is confirmed by the Correspondence Analysis, when we compare the fauna composition and abundance in streams. In Stream 1 the abundance of Ephemeroptera, "Other Coleoptera", "Other Trichoptera" and Hemiptera was high, while Stream 2 had the highest abundance of Hydrophilidae and Hirudinea. The sites of Stream 3 and 4, in the same way of PCA, were ordered intermediately between Stream 1 and 2. Ephemeroptera and Trichoptera comprise a group of organisms highly sensitive to pollution, requiring clean and well oxygenated waters for their survival (Pérez, 1988). Thus, the occurrence of these taxa is an indication of good water quality. This environmental integrity is also indicated by the group "Other Coleoptera", which includes Psephenidae, a group extremely sensitive to pollution (Junqueira and Campos, 1998) and Elmidae, that under poor environmental conditions such as depletion of dissolved oxygen, can perform drifting, increasing the possibility of finding more suitable habitats for their survival (Brown, 1987).

In contrast, the presence of Hirudinea and Hydrophilidae in Stream 2, indicates water of poor quality. It is known that leeches are very tolerant to impacted and eutrophic environments (Pérez, 1988) and Hydrophilidae is, according to the classification of Alba-Tercedor (1996), one of the families of Coleoptera more tolerant to pollution.

Although belonging to an order sensitive to pollution (Trichoptera), representatives of Hydropsychidae were sampled in streams with different degrees of environmental quality. This is an indication that this family is tolerant to pollution, confirming the results obtained by Buss et al. (2002) in a study relating the benthic macroinvertebrate community, the water chemical variablesand environmental quality in Guapimirim river basin - Rio de Janeiro - MG, Brazil.

Diptera is the most widely distributed and frequently the most abundant order of aquatic insects in freshwater environments (Armitage et al., 1983). This pattern was also evident in this study, with organisms of this order distributed throughout the stream environmental gradient in high abundances. Oligochaeta, which also showed this significant occurrence, comprises organisms extremely adaptable to degraded environments, reaching high abundances in habitats with high levels of organic matter (Fusari and FonsecaGessner, 2006; Moreno and Callisto, 2006).
The relationship between BOD and fauna, indicated in the CCA diagram could be mediated by predator-prey interactions. Since BOD and dissolved oxygen are inversely proportional variables, only groups tolerant to low oxygen concentrations are present in high BOD environments. This is the case of Mollusca and Oligochaeta, organisms with high tolerance to low concentrations of oxygen (Wetzel, 1983). Since the Hydrophilidae are predators (Merritt and Cummins, 1984) and Hirudinea also comprises some species that prey on oligochaetes (Pérez, 1988), molluscs (Gonçalves and Pellegrino, 1967) and chironomid larvae (Wetzel, 1983), it is likely that molluscs and oligochaetes are predated by Hydrophilidae and Hirudinea, thus explaining the occurrence of these taxa in high BOD environments. Additionally, Hydrophilidae and Hirudinea are groups tolerant to adverse environmental conditions (Alba-Tercedor, 1996).

Dissolved oxygen is considered one of the most important limnological variables, both for the characterization of aquatic ecosystems and for the maintenance of aquatic life. Many organisms, specially the indicators of good environmental quality require high concentrations of dissolved oxygen for their survival (Edmunds and Waltz, 1984; Pérez, 1998; Bispo et al., 2006). This situation was observed in this study, with a positive relationship between Ephemeroptera, Other Coleoptera, Other Trichoptera, Hemiptera, Odonata, Hydropsychidae and Other Diptera and oxygen concentration.

The variables BOD, organic matter, conductivity and dissolved oxygen were the most important for streams' differentiation, indicating a gradient of environmental quality, ranging from Stream 1 to Stream 2, with Streams 3 and 4 in intermediate conditions. This pattern was also noticeable for the fauna. The most sensitive groups were restricted to Stream 1 and the most tolerant groups showed higher abundances in Stream 2 and intermediate values in Streams 3 and 4. Concerning the relationship between the distribution of macroinvertebrates and environmental variables, the oxygen concentration was the most important for Ephemeroptera, Other Coleoptera, Other Trichoptera, Hemiptera, Odonata, Diptera and Other Hydropsychidae, the BOD for Hydrophilidae and Hirudinea and the turbidity for Collembola.

Thus, this study adds information about the main effects arising from environmental impacts of urbanization on benthic communities of Vereda streams. Our results also call attention to physical 
and chemical variables BOD, organic matter, conductivity, and dissolved oxygen as important factors to be considered in studies evaluating environmental quality and to explain patterns in the distribution and abundance of benthic macroinvertebrates. Oxygen concentration and BOD seem to be important variables with noticeable effects on macroinvertebrate communities and should therefore primarily be present in monitoring programs of water quality.

\section{Acknowledgements}

We thank E. F. Sousa, F. R. Camelo and all trainees for help in the field and in laboratory and Coordenação de Aperfeiçoamento de Pessoal de Nível Superior (CAPES) for the scholarship awarded to R. M. Guimarães.

\section{References}

ALBA-TERCEDOR, J. 1996. Macroinvertebrados acuáticos y calidad de las aguas de los rios. In Anais do Simposio Del Agua en Andalucía - SIAGA, 1996. Almeria. vol. 2, p. 203-213.

American Public Health Association - APHA. 1998. Standard methods for the examination of water and wastewater. Washington: APHA.

ARMITAGE, PD., MOSS, D., WRIGTH, JF. and FURSE, T. 1983. The performance of a new biological water quality score system based on macroinvertebrates over a wide range of unpolluted running - water sites. Water Research, vol. 17, no. 3, p. 333-337. http://dx.doi.org/10.1016/00431354(83)90188-4

BISPO, PC., OLIVEIRA, LG., CRISCI-BISPO, VLC. and SOUSA, KG. 2004. Environmental factors influencing distribution and abundance of trichopterans in Central Brazilian moutain streams. Studies on Neotropical Fauna and Environment, vol. 39, no. 3, p. 233-237. http://dx.doi.org/10.1080/0 1650520412331271710

BISPO, PC., OLIVEIRA, LG., BINI, LM. and SOUSA, KG. 2006. Ephemeroptera, Plecoptera and Trichoptera assemblages from riffles in mountain streams of Central Brazil: environmental factors influencing the distribution and abundance of immatures. Brazil Journal of Biology, vol. 66, n., p. 611-622.

BROWN, HP. 1987. Biology of riffle beetles. Annual Review of Entomology, vol. 32, p. 253-273. PMid:3545054. http://dx.doi.org/10.1146/annurev. en.32.010187.001345

BUCKUP, L., BUENO, AAP., BOND-BUCKUP, G., CASAGRANDE, M. and MAJOLO, F. 2007. The benthic macroinvertebrate fauna of highland streams in southern Brazil: composition, diversity and structure. Revista Brasileira de Zoologia, vol. 24, no. 2 p. $294-30$ http://dx.doi.org/10.1590/S010181752007000200005

BUSS, DF., BAPTISTA, DF., SILVEIRA, MP., NESSIMIAN, JL. and DORVILLÉ, LFM. 2002. Influence of water chemistry and environmental degradation on macroinvertebrate assemblages in a river basin in south-east Brazil. Hydrobiologia, vol. 481, no. $1-3$, p. 25-136.

BUSS, DF., BAPTISTA, DF., NESSIMIAN, JL. and EGLER, M. 2004. Substrate specificity, environmental degradation and disturbance structuring macroinvertebrate assemblages in neotropical streams. Hydrobiologia, vol. 518, no. 1-3, p. 179-188. http://dx.doi.org/10.1023/ B:HYDR.0000025067.66126.1c

CAllisto, M., MORENO, P. and BARBOSA, F. 2001. Habitat diversity and benthic funcional trophic groups at Serra do Cipó, Southeast Brazil. Revista Brasileira de Biologia, vol. 61, n. 2, p. 259-266. http:// dx.doi.org/10.1590/S0034-71082001000200008

COUCEIRO, SRM., HAMADA, N., LUZ, SLB., FORSBERG, BR. and PIMENTEL, TP. 2007. Deforestation and sewage effects on aquatic macroinvertebrates in urban streams in Manaus, Amazonas, Brazil. Hydrobiologia, vol. 575, n.1, p. 271-284.

EDMUNDS, JGF. and WALTZ, RD. 1984. Ephemeroptera. In: MERRIT, RW. and CUMMINS, KW., eds. Aquatic insects of North America. Dubuque: Kendal/Hunt Publishes. p. 126-163.

FUSARI, LM. and FONSECA-GESSNER, AA. 2006. Environmental assessment of two small reservoirs in southeastern Brazil, using macroivertebrate community metrics. Acta Limnologica Brasiliensia, vol. 18, no. 1, p. 89-99.

GONÇALVES, MDG. and PELLEGRINO, J. 1967. Predatory activity of Helobdella triserialis (Blanchard, 1849) upon Biomphalaria glabrata under laboratory conditions. Journal of parasitology, vol. 53, no. 30, p. 30-30.

GREENBERG, AE., CLESCERI, LS. and EATON, AD. 2005. Standard Methods for Examination of Water and Wastewater. Washington: American Public Health Association. 937 p.

HEPP, LU. and SANTOS, S. 2009. Benthic communities of streams related to different land uses in a hydrographic basin in southern Brazil. Environmental Monitoring and Assessment, vol. 157, no. 1-4, p. 305318. PMid:18843547. http://dx.doi.org/10.1007/ s10661-008-0536-7

HYNES, HBN. 1970. The ecology of running waters. Canada: University of Toronto Press. 555 p.

Instituto Nacional de Estatístic. 2007. Populaçōes residentes, em $1^{\circ}$ de abril de 2007, segundo os municipios. Available from: <http://www.ibge.gov. br/home/estatistica/populacao/contagem2007/ popmunic2007layoutTCU14112007.pdf >. Access in: $20 \mathrm{fev} 2008$. 
JUNQUEIRA, VM. and CAMPOS, SCM. 1998. Adaptation of the "BMWP" method for water quality evaluation to Rio das Velhas watershed (Minas Gerais, Brazil). Acta Limnologica Brasiliensia, vol. 10, no. 2, p. $125-135$

KÖEPPEN, W. 1948. Climatologia: con un estudio de los climas de la tierra. Mexico: Fondo de Cultura Economica. 479 p.

MACÊDO, JAB. 2003. Métodos laboratoriais de análises físico-químicas e microbiológicas. Belo Horizonte: CRQ-MG. 450 p.

MAIER, MH. 1987. Ecologia da bacia do rio Jacaré Pepira (47055'W; 22030', 21055'S-Brasil): qualidade da água do rio principal. Ciência e Cultura, vol. 39, no. 2, p. 164-185.

MARQUES, MM. and BARBOSA, F. 2001. Biological quality of waters from an impacted tropical watershed (middle Rio Doce basin, southeast Brazil), using benthic macroinvertebrate communities as an indicator. Hydrobiologia, vol. 457, no. 1-3 p. 69-76.

MERRIT, RW. and CUMMINS, KW. 1984. An introduction to the aquatic insects of North America. Dubuque: Iowa, Kendal/Hunt Publishes. 862 p.

MORENO, p. and CALLISTO, M. 2006. Benthic macroinvertebrates in the watershed of an urban reservoir in southeastern Brazil. Hydrobiologia, vol. 560, no. 1, p. 311-321. http://dx.doi.org/10.1007/ s10750-005-0869-y

OLIVEIRA-FILHO, EC. and MEDEIROS FNS. 2008. Ocupação humana e preservação do ambiente: um paradoxo para o desenvolvimento sustentável. In: PARRO, LM., AGUIAR, LMS., DUBOC, EC., OLIVEIRA-FILHO, AJA. and CAMARGO, FGA., eds. Cerrado: desafios e oportunidades para o desenvolvimento sustentável. Planaltina: Embrapa Cerrados. p. 33-61.

OLIVEIRA, PS. and MARQUIS, RJ., eds. 2002. The Cerrados of Brazil: ecology and natural history of a Neotropical savanna. New York: Columbia University Press. 398 p.

PREGNOLATO, W. and PREGNOLATO, NP. 1985. Normas Analíticas do Instituto Adolfo Lutz: métodos químicos e físico-químicos para análise de alimentos. São Paulo: Instituto Adolfo Lutz. 533 p.

RIBEIRO, JF., FONSECA, CEL. and SOUSA-SILVA, JC., eds. 2001. Cerrado: caracterização e recuperação de matas de galeria. Planaltina: EMBRAPA Cerrados. $899 \mathrm{p}$.

RIGHI, G. 2002. Anelídeos Oligoquetos. In: ISMAEL, D., VALENTI, WC., MATSUMURA-TUNDISI, T. and ROCHA, O., eds. Biodiversidade do Estado de São Paulo, Brasil: Invertebrados de água doce. São Paulo: FAPESP. p. 81-84.
PÉREZ, GR. 1988. Guía para el estudio de los macroinvertebrados acuáticos del departamento Antioquia. Bogotá: Editorial Presença. 217 p.

ROSENBERG, DM. and RESH, VH. 1993. Freshwater Biomonitoring and Benthic Macroinvertebrates. New York: Chapman Hall. 504 p.

SCHIAVINI, I. and ARAUJO, GM. 1989. Considerações sobre a vegetação da Reserva Ecológica do Panga (Uberlândia). Revista Sociedade e Natureza, vol. 1, no. 1, p. 61-66.

SHEPHERD, GJ. 2004. FITOPAC-SHELL 1.5: Manual do usuário. Campinas: Universidade Estadual de Campinas. 88 p.

SILVA, EM. and ASSUNÇÃO, WL. 2004. O clima na cidade de Uberlândia - MG. Revista Sociedade e Natureza, vol. 16, no. 30, p. 91-107.

TERBRAAK, CJF. and SMILAUER, P. 2002. CANOCO Reference manual and CanoDraw for Windows user's guide: Software for Canonical Community Ordination. version 4.5. Ithaca: Microcomputer Power.

VALENTE, JPS, PADILHA, PM. and SILVA, AMM. 1997. Contribution of Botucatu - SP with nutrients (phosphorus and nitrogen) to the eutrophication of the Barra Bonita dam. Eclética Química, vol. 22, p. 31-28.

WALLACE, JB. and WEBSTER, JR. 1996. The role of macroinvertebrates in stream ecosystem function. Annual Review of Entomology, vol. 41, 115-139. PMid:15012327. http://dx.doi.org/10.1146/ annurev.en.41.010196.000555

WANTZEN, M., SIQUEIRA, A., CUNHA, CN. and PEREIRA DE SÁ, MF. 2006. Stream-valley systems of the Brazilian Cerrado: impact assessment and conservation scheme. Aquatic Conservation, vol. 16, no. 7, p. 713-732. http://dx.doi.org/10.1002/ aqc. 807

WARD, D., HOLMES, N. and JOSÉ P. 1995. The New Rivers and Wildlife Handbook. Bedfordshire: RSPB, NRA, The Wildlife Trusts. 426 p.

WETZEL, RG. 1993. Limnologia. Lisboa: Fundação Calouste Gugelheim. 919 p.

WHILES, MR. and WALLACE, JB. 1997. Leaf litter decomposition and macroinvertebrate communities in headwater streams draining pine and hardwood catchmants. Hydrobiologia, vol. 353, no. 1-3, p. 107-119.

WIGGINS, G B. 1977. Larvae of the North American Caddisfly Genera (Trichoptera). Toronto: University of Toronto. $457 \mathrm{p}$.

WOODCOCK, TS. and HURYN, A. 2007. The response of macroinvertebrate production to a pollution gradient in a headwater stream. Freshwater Biology, vol. 52, no. 1, p. 77-196. 